\title{
Comparative Study of Koha Usage in Bowen University and University of Ilorin Libraries
}

\author{
Kamal Tunde Omopupa ${ }^{1}$, Ayansewa Adeleke Adedeji ${ }^{2}$, Adetola Ayotunde Kehinde ${ }^{1}$, \\ Ahmed Usman Abdulsalam ${ }^{3}$, Hajarat Abubakar ${ }^{3}$ \\ ${ }^{1}$ University of Ilorin, Department of Library and Information Science, Ilorin, Nigeria \\ ${ }^{2}$ Government College School Library, Apata, Ibadan, Oyo State \\ ${ }^{3}$ Kwara State College of Education llorin, Library \\ ORCID: K.T. Omopupa (0000-0003-4252-4681), A.A. Adedeji (0000-0001-6031-1255) A.A. Kehinde (0000-0003-4168-1511), \\ A.U. Abdulsalam (0000-0001-8203-0817), H. Abubakar(0000-0001-5451-1170)
}

\begin{abstract}
The study is comparative on Koha usage in Bowen University and University of Ilorin Libraries. It adopted a descriptive survey research design. The sample size for the was 50 professional and para-professional librarians who usually make use of Koha Integrated Library System (ILS) at the University of Ilorin library and Bowen University Library (Timothy Olagbenro Library). The questionnaire, interview and observation were used as data collection instruments. The survey was validated while the reliability coefficient of the tool using Cronbach's Alpha found to have 0.746 correlation coefficient. The IBM SPSS version 21.0 used for the analysis of the questionnaire with simple frequency counts and percentage in tables. Similar reasons were for the adoption of Koha software in both institution libraries, and those justifications could be summarised based on philosophical and ethical reasons. The extent of Koha usage at the University of Ilorin Library is low while its usage is very high extent Kohaat the Bowen University Library. Also, findings showed that the usage of Koha software is effective and efficient in University of Ilorin library and Bowen University Library. Lastly, the two selected academic libraries are not without one or two challenges in the use of Koha. At the Bowen University Library, inadequate power supply and system crashing are the challenges affecting their usage of Koha. Whereas at the University of Ilorin library, insufficient workforce; high cost of maintenance; inadequate funding; lack of training and retraining of staff; and insufficient technical knowledge were the challenges faced in the practical usage of Koha ILS. Among other recommendations, the study recommended that university libraries should collaborate with ICT experts and bodies to develop personalised quality library software.
\end{abstract}

Keywords: Koha, ILS, Software, Open Source Software, Library Software, University Library

\section{INTRODUCTION}

Humans now lived in a dynamic world that is characterised by change with operations of routines that have experienced changes in the way things are now being performed and by extension affecting informal and formal sectors of the society. In today's changing librarianship environment, library software has positioned itself as an indispensable tool in offering library services. Library software packages, designed and performed specific library functions or Information Communication Technology (ICT) operations. Library software enables librarians and information service providers to enhance their job efficiency, improve accuracy, provide timeliness, and effortless services (Olawale \& Adetimirin, 2011).

Development of numerous library software packages for the management of information resources and provi-

*Yazışma Adresi / Address for Correspondence:

T. Omopupa,Email: omopupa_kt@yahoo.com

Geliş Tarihi / Received Date: 23.05.2020

Kabul Tarihi / Accepted Date: 10.09.2020

Doi: $10.26701 /$ uad.741713 sion of library services are now evolving; these software packages include, but not limited to, Green Stone Software, ALICE for Windows, EBSCO Software, Graphical Library Automation System (GLAS), Microsoft Access Software, WebLis, Docuware, Evergreen Software, CD-ISIS, DSpace, TINLIB, VTLS (Anyaogu, 2003; Kari \& Baro, 2014). Meanwhile, previous studies unveiled examples of library software (Ayanogu 2003; Kari and Baro, 2014) that are broad with some databases and Integrated Library Software (ILS) which is the focus of this study. Tella, Dina, Olaniyi, Memudu, and Oguntayo (2017) found the adoption of library software packages by commercial agencies while others were developed indigenously by institutions for domestic use but yet other categories were customised applications based on existing software.

Selection of software and integration of resources in the libraries are critical when necessary to bring improved service quality to its operations. Ogbenege and Adetimirin (2013) recommend that for the selection of library software, it is pertinent for the library management to carefully select library software to achieve success in 
library automation and to eliminate wastage. Consequently, Ogbenege and Adetimirin (2013) opine that in as much as it is expedient for university libraries to provide efficient services; libraries should select the most appropriate software for its use. Ogbenege and Adetimirin (2013) further noted that without good software adopted and used in the library, it might not be able to perform effectively and efficiently.

Libraries should not just adopt any software without considering factors from the tenets in library software recommendation. Before the selection of any library software for integration, Mulla and Chandrashekara (2011) suggested evaluation of each module in the integrating software, experimenting with demos of the software and vendor approaches. Also, cost-effectiveness in selecting library software, hardware connection, subscribers' right, pricing structure, level of sophistication, support issue, reference site, operating system, memory requirements and programming language should be looked into when selecting library software (Fatoki, 2002; Oketunji, 2006).

No doubt, University Library is the hub of academic activities in the university, and this perhaps has made it imperative for libraries to embrace the application of modern ICT in meeting the demand of their users. Any university library that is still using a standard card catalogue can be said to have been living in the past while in the present. The dynamic environment and the use of existing software to manage library routine have made it convenient to render efficient and effective library services to their users (Omeluzor, Adara, Ezinway, Bamidele \& Umahi, 2012).

Library users expect to have a quick response to queries as well as easy access to the available information materials. Omeluzor et al. (2012) noted that automating the library is a unique decision that helps the library to provide secure and prompt service to library users. Among the available library software packages, Koha is the most advanced open-source Integrated Library System (ILS) used today by several libraries worldwide (Kumar, 2013). Projektlink (2010) also affirm that Koha is the first opensource integrated library software (ILS) used worldwide in libraries developed and steered by a growing community of libraries and users collaborating to achieve their technological goals.

Chauhan (2018) posits that Koha is a useful library management system in providing various library services to users, including the circulation of library materials. Also, the web-based nature of Koha makes it flexible and portable. Koha enables the management of libraries to act as the "driver" rather than just a mere passenger in the application of technology in library operations (Paul, 2010). Therefore, the integration of library software inferred to enable libraries to provide effective and efficient services to the user with positive feedback based on best practices. Also, the integration of library software is to help the li- brary users to have better experience in the use of library resources.

University libraries like Bowen University Library and University of Ilorin library adopt Koha as their library software on the diverse premised reasons for migration. The particular reasons for migrating to Koha ILS may have a significant effect on the usage. Apart from this, Bowen University Library has been using Koha software since 2007 while the University of Ilorin adopted Koha ILS in 2012, five years after Bowen university library adoption of Koha ILS. The difference in the year of the approval may also affect the utilisation of Koha in the two university libraries. The University of Ilorin Library is a Federal tertiary institution Library with categories of users almost the same with privately-owned Bowen University Library. These two universities are part of the top-rated universities in Nigeria. There is a need to establish an empirical framework about reasons for Koha ILS adoption and usage by these two university libraries in Nigeria.

Several studies conducted on the use of Koha library software in the libraries include Ogbenege and Adetimirin (2013) investigated the selection and use of Koha software in two private Nigerian universities. Also, Tella et al. (2017) assessed the use of Koha library software in four selected university libraries in Nigeria. Chauhan (2018) also evaluated the use of Koha library management software in Sonipat. None of these studies $(\mathrm{Og}-$ benege \& Adetimirin, 2013; Tella et al., 2017; Chauhan, 2018) focused on the reasons for the adoption of Koha library software. Also, almost nothing was done to compare the adoption and use of Koha software between the privately-owned university and public owned university. All these gaps needed to be bridged and this necessitates the urgency to do a comparative study on Koha usage in Bowen University library (Timothy Olagbenro Library) and University of Ilorin library.

\subsection{Objectives of the Study}

The objectives of this study are to:

- ascertain reasons for migrating to Koha ILS from the initial Integrated Library System formerly used in Bowen University and University of Ilorin main Libraries;

- evaluate the extent of Koha Usage in Bowen University and University of Ilorin Main Libraries;

- determine the effectiveness and efficiency of Koha in the operations of the two University main Libraries' operations; and

- investigate the challenges faced by the Bowen University and University of Ilorin main Libraries on the use of Koha software.

\subsection{Research Questions}

The following formulated research questions were to an- 
swer the research questions:

- What are the reasons for Bowen University and University of Ilorin main Libraries' migration to Koha software?

- What are the extents of Koha usage in Bowen University and University of Ilorin main Libraries?

- How effective and efficient is Koha software in Bowen University and University of Ilorin main Libraries' operations?

- What are the challenges faced by Bowen University and University of Ilorin Main Libraries in utilising Koha software?

\subsection{Literature Review}

Macan, Fernández, and Stojanovski (2013) affirm that the word "Koha" is not an acronym. It implies that "Koha" should not be in upper case as "KOHA". Koha is a Maori word. "Koha" as a Maori word, is a special kind of gift, most accurately defined as a gift with expectations. It is one of the reasons why the Koha ILS licensed with the GPL because in the hopes of reciprocity built in it. Downloading of Koha from its official site: https://www. koha-community.org/download-Koha/ has several with improvements have gone into ILS which Koha was not an exemption. On April 2012, Koha developer team announced the release of Koha 3.8.0, the third major release since the group shifted to time-based releases. According to Cormack (2012), Koha 3.8.0 contains over 130 enhancements with over 1000 changesets from 71 developers. It is pertinent to add that based on a publication on the Koha community website that Koha is the first free and open-source ILS package. The sponsored of the development supported by libraries of varying types and sizes, volunteers, and support companies from around the world http://Koha-community.org/Koha-3-8-0-released/

The Koha users' community that has grown over the years have made meaningful contributions to the improvement of the ILS given users the leverage to enjoy the software in their various libraries, and its code available at http:// git.Koha-community.org. The bug/enhancement list at http://bugs.Koha-community.org. Pund (2016) revealed that over 300 libraries are using Koha, including academic, public, school and special libraries, in Africa, Australia, Canada, USA, France, India and, of course, New Zealand. Along with a committed team of programmers, its development steered by a growing community of libraries collaborating to achieve their technology.

\subsection{The relevance of Koha in the Libary}

Omeluzor et al. (2012) noted that Koha is an open-source Integrated Library System has no vendor to dictate and argue issues with librarians. It has a customisable OPAC that can display vital information about the institution and other relevant sites. Bearing in mind challenges that were usually faced by librarians to meet users' needs, Koha has a good prospect. The Study further stated that Koha users' community that has grown over the years had made meaningful contributions to the improvement of the ILS given users the leverage to enjoy the software in their various libraries. Omeluzor et al. (2012) conclude that:

"Koha's ability to accommodate a large collection, ability to integrate the basic library operations, easy to configure, quick response time, menu-driven, adaptable to other systems/software, easy to use and zebra crossing among others makes it a viable option for the University Library."

Riewe (2008) found that open source ILSs were more cost-effective than proprietary ILSs. Libraries using open source ILSs chose them mainly for affordability. The study added that users of open source ILSs experienced difficulties with installation and incomplete documentation that were modestly more satisfied than users of proprietary ILSs. Zico (2009) stated that the web-based nature of Koha makes it flexible and portable. There is no need for installation of Koha on every machine to use it. The installation of Koha in a server and it serves through Internet Protocol Address or its website.

According to Zico (2009), Koha was installed on a server and was accessed via Internet Protocol (IP) address or the Uniform Resource Locator (URL) thereby eliminating the need to install third-party software like Microsoft Visual Basic to have a complete Library management system. All that is needed is a web browser from which the ILS can access any computer connected to the Internet. Zico (2009) also states that the Koha installation. Customisation included the user interface, policymaking, system preferences, budget making, item type administration and vendor organisation. The study also observed that the open-source nature of Koha makes for easy access to support for developers, users and maintainers. In his overview of the security system of Koha ILS, Zico (2009) noted that the OPAC grants access to documents on the Koha. Also Koha's different levels of access from System Administrator to the part-time employee of the library. Similarly, in a study of the automation of Adeyemi College of Education Library, Egunjobi and Awoyemi (2012) observe that automation can improve the library's relevance to the academic community. The study further revealed that library staff enjoy working in an automated environment, and the patrons enjoy services rendered using an OPAC instead of a card catalogue.

Another finding (Akinbobola and Adeleke 2013) suggest that the Koha software meets library personnel's specifications with the ability to meet their needs effectively and efficiently. It further stated that Library personnel have the capability and are confident in their ability to use computers to perform well with the Koha software. 


\subsection{Empirical Review}

A survey of the factors affecting actual system use, Akinbobola and Adeleke (2013) posit that that usability, supportive management, and computer self-efficacy strongly influenced library personnel's actual use of the Koha software system. The study also stated that Computer self-efficacy takes precedence over other variables in influencing actual system use. Akpokodje and Akpokodje (2015) conducted a study on "Assessment and Evaluation of Koha ILS for Online Library Registration at University of Jos, Nigeria". The study reveals that majority of library staff $(92 \%)$ confirmed that chosen Koha ILS in their libraries out of necessity, $50 \%$ said it was because it was secure, $71 \%$ said it was because it was easy to use, $83 \%$ said it was desirable to them, $63 \%$ implicated the available features and functionality, $54 \%$ said it was because it has a trusted brand name while $58 \%$ said because of its affordability. Akpokodje and Akpokodje (2015) concluded that Koha was selected at the University of Jos library out of necessity and not thoroughly planned.

Edem and Bassey (2016) conducted a study on Adoption of Software Packages in University Libraries in Nigeria revealed that Koha software is the only software that has the highest rate of adoption/usage in Academic libraries in Nigeria. According to him, some of the academic libraries using Koha are Babcock University Library; Federal University Lokoja Library; Adeyemi College of Education Library; Redeemers University Library; Taisolarin University of Education Library, Lagos State University Library; Bowen University Library; the University of Ilorin Library, among others.

Consequently, Ogbenege and Adetimirin (2013) investigated the selection and use of the Koha software by library staff and faculty in two private university libraries. The study employed a descriptive survey with a sample size of 255 from a total population of 418 faculty, systems librarians and heads of library units from two private universities (Bowen and Redeemers). The study adopted questionnaires, interviews and observation for data collection out of which the 255 copies of the questionnaire distributed, 176 were completed (70.4 per cent). Redeemer University (RU) had the highest number of respondents (101), while Bowen University (BU) had the lowest number of respondents of (75). On the level and length of use of Koha software, findings indicated that the frequency of use of the software by the faculty was not encouraging. It may be due to their busy schedules which include teaching, research and community service.

Similarly, Kari and Baro (2014) examined the use of library software in Nigerian University Libraries and their challenges. The study adopts a purposive sampling technique to select sixty-two (62) university libraries which were known to have used at least one library software. The study forwarded the questionnaire to the university librarians, who either responded to it or forwarded it to the librarian in charge of the automation project. Out of the 62 , copies sent university libraries questionnaire sent, thirty-six (36) were received and used for analysis. All the questionnaires were found useful and reported to have been collated, analysed and presented in charts. Findings from the study showed that lack of skilled human resources, lack of funding, lack of system (computers) and erratic power supply are the significant problems university libraries in Nigeria encountered while using library software.

\section{METHODOLOGY}

The descriptive survey research design was found appropriate and used for the current study while the population of the study comprises of professional and paraprofessional library staff that usually make use of Koha in the discharge of their duties. The population of the study is 50 professional and para-professional librarians who usually make use of Koha at the University of Ilorin library and Bowen University Library. The study used total enumerative sampling technique to determine the study sample size. The technique was found suitable because of the population size. The study adopts triangulation in which Questionnaire, interview and observation were used as data collection instruments. The questionnaire was content validated while the reliability coefficient of the instrument using Cronbach's Alpha found to have 0.746 correlation coefficient. Out of the 50 copies of the questionnaire administered, 46 copies of the questionnaire retrieved. The data collected from the field analysed using descriptive statistics including simple percentage and frequency counts while the data coded using SPSS version 24.0.

Table 1 shows that at the University of Ilorin library, 16 (61.5\%) of the respondents were female, while 10 (38.5\%) were male. At the Bowen University Library, 16 (80.05) of the respondents were female while 4 (20.0\%) were male. Also, Table 1 shows that at the University of Ilorin library, 5 (19.2\%) of the respondents were between 25-35 years, 17 (65.4\%) were between 36-45 years and 4 (15.4\%) were between 46-55 years. Whereas at the Bowen University Library, 6 (30.0\%) were between 25-35 years, 12 (60.0\%) were between $36-45$ years and $2(10.0 \%)$ were between 46-55 years. Table 4.1 further reveals that at the University of Ilorin library, 6 (23.1\%) of the respondents have 1-5 years of working experience, 13 (50.0\%) have 6-10 years of working experience, 4 (15.4\%) have $11-15$ years of working experience, 1 (3.8\%) has 16-20 years of working experience and 2 (7.7\%) have above 20 years of working experience. However, at Bowen University Library, 13 (65.0\%) of the respondents have 1-5 years of working experience, 3 (15.0\%) have 6-10 years of working experience, 2 (10.0\%) have 11-15 years of working experience, and 2 (10.0\%) have 16-20 years of working experience. Lastly, Table 4.1 reveals that at the University of Ilorin library, 4 (15.4\%) of the respondents were Librarian I, 5 (19.2\%) were Li- 
Table 1. Demographic Information of the Respondents

\begin{tabular}{|c|c|c|c|c|}
\hline & \multicolumn{2}{|c|}{$\begin{array}{c}\text { University of Ilorin } \\
\text { Library }\end{array}$} & \multicolumn{2}{|c|}{$\begin{array}{c}\text { Bowen University } \\
\text { Library }\end{array}$} \\
\hline & Frequency & Per cent & Frequency & Per cent \\
\hline \multicolumn{5}{|l|}{ Gender } \\
\hline Female & 16 & 61.5 & 16 & 80.0 \\
\hline Male & 10 & 38.5 & 4 & 20.0 \\
\hline Total & 26 & 100 & 20 & 100 \\
\hline \multicolumn{5}{|l|}{ Age } \\
\hline 25-35 Years & 5 & 19.2 & 6 & 30.0 \\
\hline 36-45 Years & 17 & 65.4 & 12 & 60.0 \\
\hline 46-55 Years & 4 & 15.4 & 2 & 10.0 \\
\hline 56-65 Years & - & - & - & - \\
\hline Total & 26 & 100 & 20 & 100 \\
\hline \multicolumn{5}{|l|}{ Years of Experience } \\
\hline 1-5 Years & 6 & 23.1 & 13 & 65.0 \\
\hline 6-10 Years & 13 & 50.0 & 3 & 15.0 \\
\hline $11-15$ Years & 4 & 15.4 & 2 & 10.0 \\
\hline $16-20$ Years & 1 & 3.8 & 2 & 10.0 \\
\hline 20 Years and above & 2 & 7.7 & - & - \\
\hline Total & 26 & 100 & 20 & 100 \\
\hline \multicolumn{5}{|l|}{ Designation } \\
\hline Librarian I & 4 & 15.4 & 2 & 10.0 \\
\hline Librarian II & 5 & 19.2 & 8 & 40.0 \\
\hline Senior Librarian & 8 & 30.8 & - & - \\
\hline Principal Librarian & - & - & - & - \\
\hline Higher Library Officer & 5 & 19.2 & 6 & 30.0 \\
\hline System Analyst & 1 & 3.8 & 1 & 5.0 \\
\hline $\begin{array}{c}\text { Principal Library } \\
\text { Officer }\end{array}$ & 2 & 7.7 & 3 & 15.0 \\
\hline $\begin{array}{c}\text { Assistant Library } \\
\text { Officer }\end{array}$ & 1 & 3.8 & - & - \\
\hline Total & 26 & 100 & 20 & \\
\hline
\end{tabular}

brarian II, 8 (30.8\%) were Senior Librarian, 5 (19.2\%) were Higher Library Officers, 1 (3.8\%) was system analyst, 2 (7.7\%) were Principal Library Officers and 1 (3.8\%) was Assistant Library Officer. Whereas, at the Bowen University Library, 2 (10.0\%) of the respondents were Librarian I, 8 (40.2\%) were Librarian II, 6 (30.0\%) were Higher Library Officers, 1 (5.0\%) was system analyst and 3 (15.0\%) were Principal Library Officers.

\subsection{Justification for the adoption of Koha}

Table 2 indicates the reasons why the University of Ilorin Library and Bowen University Library chose Koha. In the university of Ilorin, the most significant Justification for the adoption of Koha software are because of Koha's User-friendliness, Flexibility, Low cost of purchase, Low cost of maintenance, reliability, Availability of Search Engine and for an upgrade. All these have a mean value of 1.00 because all the staff indicated in their response. Similarly, the chief reasons why Bowen University Library chose Koha are because of Koha's User-friendliness, flexibility, efficiency, reliability. It also has a mean value of 1.00 meaning all the respondents (staff) agreed to this reason. Reason based on Low cost of purchase is the primary distinction between the university of Ilorin and Bowen University libraries.
Table 2. Justification for the Adoption of Koha

\begin{tabular}{|c|c|c|c|c|c|c|}
\hline & \multicolumn{3}{|c|}{ UNILORIN Library } & \multicolumn{3}{|c|}{ Bowen University Library } \\
\hline $\begin{array}{l}\text { Justification for } \\
\text { Adoption }\end{array}$ & YES & NO & Mean & YES & NO & Mean \\
\hline \multirow{2}{*}{$\begin{array}{l}\text { User-friend- } \\
\text { liness }\end{array}$} & 26 & 0 & & 18 & 2 & \\
\hline & $(100.0 \%)$ & $(0.0 \%)$ & 1.00 & $(90.0 \%)$ & $(10.0 \%)$ & 1.00 \\
\hline \multirow{2}{*}{ Flexibility } & 26 & 0 & & 20 & 0 & \\
\hline & $(100.0 \%)$ & $(0.0 \%)$ & 1.00 & $(100.0 \%)$ & $(0.0 \%)$ & 1.00 \\
\hline \multirow{2}{*}{ Re-usability } & 25 & 1 & & 11 & 9 & \\
\hline & $(96.2 \%)$ & $(3.8 \%)$ & 0.96 & $(55.0 \%)$ & $(45.0 \%)$ & 0.55 \\
\hline \multirow{2}{*}{ Adaptability } & 24 & 2 & & 18 & 2 & \\
\hline & $(92.3 \%)$ & $(7.7 \%)$ & 0.92 & $(90.0 \%)$ & $(10.0 \%)$ & 0.90 \\
\hline \multirow{2}{*}{ Robustness } & 25 & 1 & & 13 & 7 & \\
\hline & $(96.2 \%)$ & $(3.8 \%)$ & 0.96 & $(65.0 \%)$ & $(35.0 \%)$ & 0.65 \\
\hline \multirow{2}{*}{$\begin{array}{l}\text { Low cost of } \\
\text { Purchase }\end{array}$} & 26 & 0 & & 16 & 4 & \\
\hline & $(100.0 \%)$ & $(0.0 \%)$ & 1.00 & $(80.0 \%)$ & (20.0\%) & 0.80 \\
\hline \multirow{2}{*}{$\begin{array}{l}\text { Low cost of } \\
\text { Maintenance }\end{array}$} & 26 & 0 & & 16 & 4 & \\
\hline & $(100.0 \%)$ & $(0.0 \%)$ & 1.00 & $(80.0 \%)$ & $(20.0 \%)$ & 0.80 \\
\hline \multirow{2}{*}{ Efficiency } & 23 & 3 & & 20 & 0 & \\
\hline & (88.5\%) & (11.5\%) & 0.88 & $(100.0 \%)$ & $(0.0 \%)$ & 1.00 \\
\hline \multirow{2}{*}{$\begin{array}{l}\text { Unified Mana- } \\
\text { gement }\end{array}$} & 24 & 2 & & 13 & 7 & \\
\hline & (92.3\%) & (7.7\%) & 0.92 & $(65.0 \%)$ & (35.0\%) & 0.65 \\
\hline \multirow{2}{*}{ Stability } & 24 & 2 & & 16 & 4 & \\
\hline & $(92.3 \%)$ & $(7.7 \%)$ & 0.92 & $(80.0 \%)$ & $(20.0 \%)$ & 0.80 \\
\hline \multirow{2}{*}{ Reliability } & 26 & 0 & & 20 & 0 & \\
\hline & $(100.0 \%)$ & $(0.0 \%)$ & 1.00 & $(100.0 \%)$ & $(0.0 \%)$ & 1.00 \\
\hline \multirow{2}{*}{$\begin{array}{c}\text { Support and } \\
\text { support model }\end{array}$} & 24 & 2 & & 16 & 4 & \\
\hline & (92.3\%) & (7.7\%) & 0.92 & $(80.0 \%)$ & $(20.0 \%)$ & 0.80 \\
\hline \multirow{2}{*}{$\begin{array}{l}\text { Ability to ma- } \\
\text { nage privileges } \\
\text { and permis- } \\
\text { sions }\end{array}$} & 25 & 1 & & 15 & 5 & \\
\hline & (96.2\%) & (3.8\%) & 0.96 & $(75.0 \%)$ & $(25.0 \%)$ & 0.75 \\
\hline \multirow{2}{*}{$\begin{array}{l}\text { Availability of } \\
\text { Search options }\end{array}$} & 26 & 0 & & 18 & 2 & \\
\hline & $(100.0 \%)$ & $(0.0 \%)$ & 1.00 & $(90.0 \%)$ & $(10.0 \%)$ & 0.90 \\
\hline \multirow{2}{*}{$\begin{array}{l}\text { Just for Upg- } \\
\text { rade }\end{array}$} & 26 & 0 & & 10 & 10 & \\
\hline & $(100.0 \%)$ & $(0.0 \%)$ & 1.00 & $(50.0 \%)$ & $(50.0 \%)$ & 0.50 \\
\hline \multirow{2}{*}{$\begin{array}{l}\text { It is the best } \\
\text { among all } \\
\text { Open Source } \\
\text { software }\end{array}$} & 26 & 0 & & 16 & 4 & \\
\hline & $(100.0 \%)$ & $(0.0 \%)$ & 1.00 & $(80.0 \%)$ & $(20.0 \%)$ & 0.80 \\
\hline
\end{tabular}

Table 3. Correlation test of the extent of Koha Usage in UNILORIN and Bowen Libraries

\begin{tabular}{|c|c|c|c|}
\hline \multicolumn{4}{|c|}{ Correlations } \\
\hline \multicolumn{2}{|c|}{} & $\begin{array}{c}\text { UNILORIN and } \\
\text { Bowen University } \\
\text { Libraries }\end{array}$ & Koha Usage \\
\hline \multirow{2}{*}{\begin{tabular}{c} 
Name of the Uni- $\begin{array}{c}\text { Pearson } \\
\text { versity } \\
\text { Correlation }\end{array}$ \\
\cline { 2 - 4 } Koha Usage
\end{tabular}} & 1 & -.086 \\
\cline { 2 - 4 } & Sig. (2-tailed) & N & .570 \\
\hline \multirow{2}{*}{$\begin{array}{c}\text { Pearson } \\
\text { Correlation }\end{array}$} & -.086 & 46 \\
\cline { 2 - 4 } & Sig. (2-tailed) & .570 & 1 \\
\cline { 2 - 4 } & $\mathrm{N}$ & 46 & 46 \\
\hline
\end{tabular}

Correlation significant at 0.01 level (2-tailed)

The result of the correlation test in Table 3 showed that there is a weak negative correlation of -.086 between Koha usage in University of Ilorin and Bowen University Libraries. It means that there is a significant difference between Koha usage in Bowen University and University of Ilorin Libraries. 
Table 4. Correlation test of the effectiveness of Koha in UNILORIN and Bowen Libraries

\begin{tabular}{|c|c|c|c|}
\hline \multicolumn{4}{|c|}{ Correlations } \\
\hline & & Effectiveness and Efficiency of Koha & UNILORIN and Bowen University Libraries \\
\hline \multirow{3}{*}{$\begin{array}{l}\text { Effectiveness and Efficiency } \\
\text { of Koha }\end{array}$} & Pearson Correlation & 1 & $-.446^{* *}$ \\
\hline & Sig. (2-tailed) & & .002 \\
\hline & $\mathrm{N}$ & 46 & 46 \\
\hline \multirow{3}{*}{$\begin{array}{l}\text { UNILORIN and Bowen } \\
\text { University Libraries }\end{array}$} & Pearson Correlation & $-.446^{* *}$ & 1 \\
\hline & Sig. (2-tailed) & .002 & \\
\hline & $\mathrm{N}$ & 46 & 46 \\
\hline \multicolumn{4}{|c|}{ **. Correlation is significant at the 0.01 level (2-tailed). } \\
\hline
\end{tabular}

Table 5. Challenges in Using Koha Software in UNILORIN and Bowen Libraries

\begin{tabular}{|c|c|c|c|c|c|c|c|c|c|c|}
\hline \multirow[b]{3}{*}{ Challenges } & \multicolumn{5}{|c|}{ University of Ilorin Library } & \multicolumn{5}{|c|}{ Bowen University Library } \\
\hline & \multicolumn{2}{|c|}{ Yes } & \multirow{2}{*}{$\begin{array}{c}\text { No } \\
\mathrm{F}\end{array}$} & \multirow[b]{2}{*}{$\%$} & \multirow[t]{2}{*}{ Mean } & \multicolumn{2}{|c|}{ Yes } & \multicolumn{2}{|c|}{ No } & \multirow[t]{2}{*}{ Mean } \\
\hline & $\mathrm{F}$ & $\%$ & & & & $\mathrm{~F}$ & $\%$ & $\mathrm{~F}$ & $\%$ & \\
\hline Insufficient manpower & 26 & 100.0 & - & - & 1.00 & 9 & 45.0 & 11 & 55.0 & 0.45 \\
\hline Lack of supervision & 1 & 3.8 & 25 & 96.2 & 0.04 & 3 & 15.0 & 17 & 85.0 & 0.15 \\
\hline Inadequate managerial support & 10 & 38.5 & 16 & 61.5 & 0.38 & 3 & 15.0 & 17 & 85.0 & 0.15 \\
\hline Inadequate power supply & 2 & 7.7 & 24 & 92.3 & 0.08 & 13 & 65.0 & 7 & 35.0 & 0.01 \\
\hline High cost of procurement & - & - & 26 & 100.0 & 0.00 & 1 & 5.0 & 19 & 95.0 & 0.01 \\
\hline High cost of maintenance & 20 & 76.9 & 6 & 23.1 & 0.77 & 10 & 50.0 & 10 & 50.0 & 0.01 \\
\hline Vendors insecurity & - & - & 26 & 100.0 & 0.00 & 2 & 10.0 & 18 & 90.0 & 01.0 \\
\hline Lack of consortium & 3 & 11.5 & 23 & 88.5 & 0.12 & 3 & 15.0 & 17 & 85.0 & 0.15 \\
\hline Library staff apathy & 2 & 7.7 & 24 & 92.3 & 0.08 & 2 & 10.0 & 18 & 90.0 & 0.10 \\
\hline Inadequate funding & 23 & 88.5 & 3 & 11.5 & 0.88 & 8 & 40.0 & 12 & 60.0 & 0.40 \\
\hline Lack of training and retraining of staff & 21 & 80.8 & 5 & 19.2 & 0.81 & 2 & 10.0 & 18 & 90.0 & 0.10 \\
\hline Piracy & 5 & 19.2 & 21 & 80.8 & 0.19 & 5 & 25.0 & 15 & 75.0 & 0.30 \\
\hline Proximity to virus & - & - & 26 & 100.0 & 0.00 & 7 & 35.0 & 13 & 65.0 & 0.25 \\
\hline Crashing problem & 12 & 46.2 & 14 & 53.8 & 0.46 & 11 & 55.0 & 9 & 45.0 & 0.55 \\
\hline Insufficient technical knowledge & 26 & 100.0 & - & - & 1.00 & 6 & 30.0 & 14 & 70.0 & 0.30 \\
\hline Data retrieval & 1 & 3.8 & 25 & 96.2 & 0.04 & 3 & 15.0 & 17 & 85.0 & 0.15 \\
\hline
\end{tabular}

Table 6. Description of Interview Scheduled

\begin{tabular}{|c|c|c|}
\hline Interview Question & University Of Ilorin Library & Bowen University Library \\
\hline $\begin{array}{l}\text { 1. When did your Library start using Koha } \\
\text { software? }\end{array}$ & 2012 & 2007 \\
\hline 2. Why chosen Koha? & $\begin{array}{l}\text { We chose Koha as a result of the deficiency of the last software } \\
\text { we used: TINLIB. }\end{array}$ & $\begin{array}{l}\text { We have been using Koha since the inception and } \\
\text { it has been helping us greatly }\end{array}$ \\
\hline $\begin{array}{l}\text { 3. Can your student have access to Koha } \\
\text { OPAC module from their remote areas? }\end{array}$ & $\begin{array}{l}\text { Yes, although this arrangement was recent and by implication, } \\
\text { not all our students are aware about this }\end{array}$ & $\begin{array}{l}\text { Yes, Koha OPAC module in our library can be } \\
\text { accessed by our student at home or abroad }\end{array}$ \\
\hline $\begin{array}{l}\text { 4. How can you rate the way Koha is being } \\
\text { used in your library? }\end{array}$ & $\begin{array}{l}\text { Well, the rate of usage is 'High' among library staff because they } \\
\text { use it to discharged their duties but the rate of usage is 'Low' } \\
\text { among students as a result of most of them not being aware. }\end{array}$ & $\begin{array}{c}\text { Koha usage in our Library is very high. Students } \\
\text { and Staff that use the software make use of it on } \\
\text { a very high level. }\end{array}$ \\
\hline 5. Modules used & $\begin{array}{l}\text { Because of the challenges we faced, we used only the Catalo- } \\
\text { guing, Circulation, Serial and Acquisition modules. Meanwhile, } \\
\text { only the Cataloguing and Circulation modules are being used to } \\
\text { the fullest; serial and acquisition modules are on partial usage }\end{array}$ & $\begin{array}{l}\text { At the Bowen University Library, we make use } \\
\text { of all the modules in Koha software. And this is } \\
\text { one of the reasons why I said Koha usage in our } \\
\text { library on a very high level }\end{array}$ \\
\hline $\begin{array}{l}\text { 6. Is your library considering migrating to } \\
\text { another library software soon? }\end{array}$ & $\begin{array}{l}\text { Well, for now, NO. The software is helping us to be better in } \\
\text { library automation process although we have not achieved this } \\
\text { fullest. It is still the best software we have used so far in our } \\
\text { library }\end{array}$ & $\begin{array}{c}\text { Not at all. We have been using it for long and } \\
\text { the software has been serving purpose with no } \\
\text { specific challenge apart from the normal disad- } \\
\text { vantages of any ICT system }\end{array}$ \\
\hline
\end{tabular}

The result of the correlation test in Table 4 showed that there is a moderate negative correlation of 446 between Koha usage in University of Ilorin and Bowen University Libraries. It implies that there is a significant difference in the effectiveness and Efficiency of Koha in Bowen University Library and the University of Ilorin Library.

Table 5 revealed the evidence that there is the disparity in the challenges facing the usage of Koha at the University of Ilorin library and Bowen University library. At the University of Ilorin library insufficient workforce $(26 ; 100 \%)$, high cost of maintenance $(20 ; 76.9 \%)$, inadequate fund- ing (23; 88.5\%), lack of training and retraining of staff (21; $80.8 \%)$ and insufficient technical knowledge (26; 100\%) were identified by majority of the respondents as challenges facing them in the use of Koha. However, at the Bowen University Library, inadequate power supply (13; $65.0 \%)$ and crashing problem $(11 ; 55.0 \%)$ were identified by the majority of the respondents as challenges facing them in the use of Koha. Also, in both institution libraries, lack of supervision, high cost of procurement, vendors insecurity, lack of consortium, library staff apathy, piracy, proximity to virus and data retrieval were not factors facing them in the use of Koha. 


\subsection{Comparative Analysis of Data Gathered through Interview}

A tape recorder was used to record the interview sessions with the e-librarian, and system analysts in the two institutions. The recorded interview was transcribed accordingly. Responses of the questions asked during the interview sessions in the two university libraries as follows:

\section{ANALYSIS OF DATA GATHERED THROUGH OBSERVATION}

Links to access OPAC module of Koha in the two university libraries were collected and the links used to perform some searches within the comfort of the researchers. The researchers critically observed the OPAC and some findings made. Snapshots of Koha homepages of Bowen University Library and the University of Ilorin Library can be found in Figures 1 and 2 respectively.

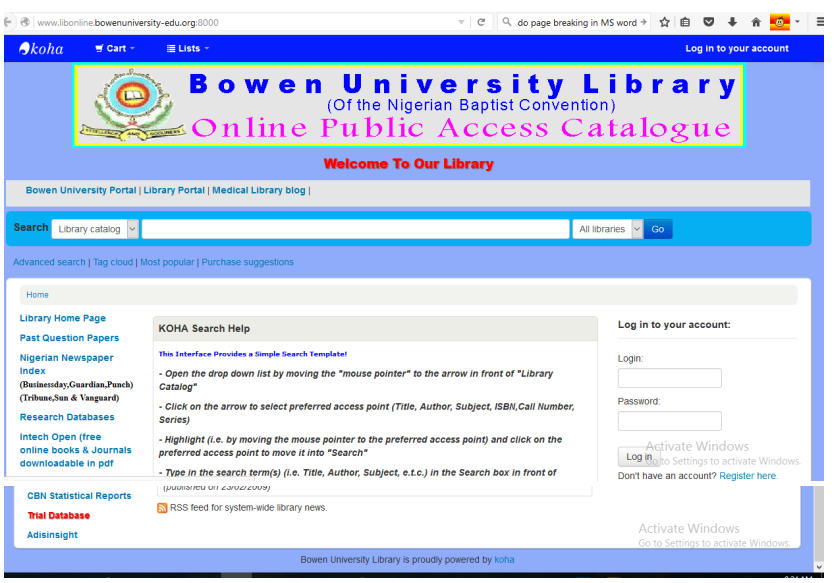

Figure 1. Snapshots of Bowen University Koha OPAC module Homepage

At Timothy Olagbenro Library (Bowen University Library), the user can have access to the modules by providing their login details. The study observed that all the titles of the books on the physical shelves found on the Koha OPAC module based on the online searches done by the researchers. Also, the Koha comment option in Bowen university library is working as expected as the comment made will be sent to the administrator in which the system analyst is part of the administrator.

The system designed to log into the students' matriculation number and the surname (all Capitalized) will be used as the username and password respectively to gain access to University of Ilorin Koha OPAC module while the Staff are to log in with their staff ID. Figure Figure 2 shows the snapshot of the Koha Homepage used in University of Ilorin Library.

Different searches conducted in the observation strictly observed that there are still some of the resources on the physical shelves in the main library that are not appearing in the OPAC module. For example, Library and Information Science Text for Africa by L.O Aina not yet included on the OPAC module as at when this report was being collated and it is on the shelf. Also, a textbook by Issa, A.
O. on Practical Guides to Project Writing for Students in Colleges of Education, Polytechnics and Universities was not found on the OPAC module (See Figure 3), and it is on the Shelf at the basement floor of the library Perhaps this is as a result of the enormous library collection of university of Ilorin Library and that the automating process is ongoing.

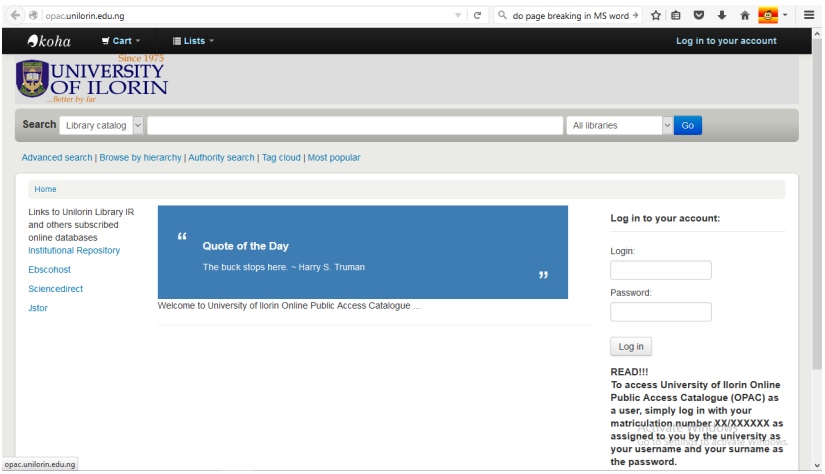

Figure 2. Snapshot of Koha homepage used in UNILORIN library

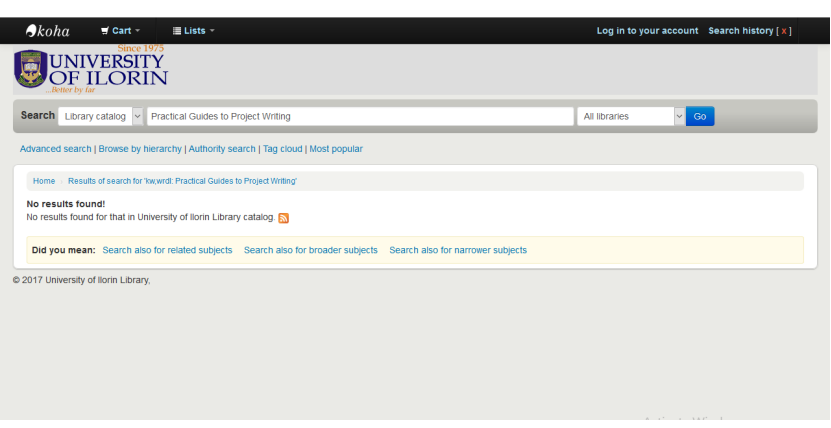

Figure 3. Snapshot of Koha in UNILORIN Library showing some searches that are not found

\section{DISCUSSION OF THE FINDINGS}

There are numerous justifications for the adoption of Koha software at the University of Ilorin Library and Bowen University Library. However, finding for this study revealed that there are similarities in the justification for the adoption of Koha software in both institution libraries and those justifications summarised on philosophical and ethical reasons. The finding corroborates Gonzalez-Barahona (2000) as cited in Ukachi et al. (2014) who categorised the benefits associated with the use of opensource software like Koha into philosophical and ethical benefits.

On the extent of Koha usage at the University of Ilorin library and Bowen University library, finding from this study revealed that there is the low extent of Koha usage at the University of Ilorin Library while there is the very great extent of usage of Koha at the Bowen University Library. It implies that there is high usage of Koha in Bowen University Library than the University of Ilorin Library. It is because library users (especially students) in Bowen University are accessing and utilising OPAC module of the software to the fullest unlike in University of Ilorin. Also, form the observation, the researcher observed that most services rendered to library users in Bowen University are done with the aid of all the modules in Koha 
whereas in the University of Ilorin only two of the modules (cataloguing and circulation modules) are fully used. The finding on the extent of usage of Koha software at the Bowen University Library contradicts the findings of Ogbenege and Adetimirin (2013) who reported that the frequency of use of the Koha software by the faculty was not encouraging. It may be due to their busy schedules which include teaching, research and community service when compare to the librarians who use the software for rendering library services. On the effectiveness and efficiency, findings from the two institution libraries show that Koha software is effective and efficient in usage. This finding corroborates Akinbobola and Adeleke (2013) who reported that Koha software meets library personnel's specifications and has the ability to fulfil their needs effectively and efficiently.

The two selected academic libraries are not without one or two challenges in the use of Koha, at the Bowen University Library inadequate power supply and the crashing problem identified as the challenges affecting their usage of Koha. Whereas at the University of Ilorin library, insufficient workforce; high cost of maintenance; inadequate funding; lack of training and retraining of staff; and insufficient technical knowledge found as the challenges affecting their usage of Koha. This finding is similar to some studies (Ming, 2000; Kari \& Baro, 2014; Ayodele, 2015) who have identified software problems, unreliable power supply, inadequate funding, staff training deficien$c y$, the inadequate pool of relevant technical staff with the problem or difficulty in their recruitment and retention.

\section{CONCLUSION AND RECOMMENDATIONS}

Koha, is open-source software, is witnessing an increase in usage in libraries. Both private and government own academic libraries make of this software. The way and manner this software used differently in Bowen University library compared to the University of Ilorin. Based on the findings of this study, it is worthy to strongly affirm that Koha is being used on a very high level in Bowen University Library (Timothy Olangbenro library) unlike the University of Ilorin Library where there is low usage. Hence, the two university libraries studied have similar reasons for adopting Koha ILS but the two libraries differ in terms of Koha usage after adopting the software. There is a direct relationship in the justification for Koha Usage in Bowen University Library and the University of Ilorin but there is a parallel relationship in the extent of Koha usage between the two university libraries. Based on the findings of this study and conclusion recommended that:

- The management of Bowen University should ensure they provide a solar system for its library (Timothy Olagbenro Library) as suggested by one of the staff in order to serve as an alternative source of power supply for network and services device. It will enable uninterrupted access and usage of Koha software in the university at large.

- Also, the management of the University of Ilorin should ensure additional allocation fund for the maintenance of the library software.

- The University of Ilorin Library should integrate all the modules of Koha for increased effectiveness and efficiency in their operations.

- The management of the University of Ilorin Library should employ more workforce.

- The management of Bowen University, as well as the university of Ilorin, must ensure that they guide against the aftermath effect of system crashing by backing up their data from time to time.

- University libraries should collaborate with ICT experts and bodies to develop personalized quality library software since personalised library software will go a long way in suiting the need of the library as well as its aim and objectives.

\section{REFERENCES}

Adesola, A. P., \& Olla, G. O. O. (2018). Unlocking the Unlimited Potentials of Koha OSS/ILS for Library House-Keeping Functions.

Akinbobola, O. I., \& Adeleke, A. A. (2013).The influence of user efficacy and expectation on actual system use. Interdisciplinary Journal of Information, Knowledge, and Management, 8(1), 43-57.

Akpokodje, V. N., \&Akpokodje, T. E. (2015).Assessment and evaluation of Koha ILS for online library registration at the University of Jos, Nigeria.

Anyaogu, U. (2003). Assessing the catalogue module of Alice for window software. Lagos Journal of Library and Information Science, 1(1), 42-46.

Chauhan, K. (2018). Evaluation in use of Koha Library Management Software in OPJGU, Sonipat. Library Philosophy and Practice, 1-13.

Cormack, C. (2012). Koha 3.8. 0 Released. Koha Library Software Community.

Edem, M. B., \& Bassey, R. S. (2016). Adoption of software packages in university libraries in Nigeria. Library Philosophy and Practice.

Egunjobi, R. A., \& Awoyemi, R. A. (2012).Library automation with Koha. Library Hi Tech News, 29(3), 12-15.

Faboyinde, E. O. (2006). The state of information and communication technology (ICT) in selected libraries in Lagos and Ibadan metropolis. Libraries: Dynamic Engines for the Knowledge and Information Society, 126.

Fatoki, O. C. (2002). Trends and standards in software selection in Nigerian Libraries.

Kari, H. K., \& Baro, E. E. (2014). The use of library software in Nigerian University Libraries and challenges. Library Hi Tech News, 31(3), 15-20.

Macan, B., Vanesa Fernández, G., \&Stojanovski, J. (2013). Open source solutions for libraries: $A B C D$ vs Koha. Program, 47(2), 136-154. 
Mulla, K. R., \&Chandrashekara, M. (2011). Bibliometric analysis of literature on industry and trade. Information Studies, 17(2), 99-114.

Ogbenege, J., \&Adetimirin, A. (2013).Selection and use of Koha software in two private Nigerian universities. Library $\mathrm{Hi}$ Tech News, 30(6), 12-16.

Oketunji, I. (2006). Choice of library application and their sustainability: necessary guidelines. Proceedings of selected papers cataloguing, Classification and Indexing of Section of NLA, 48-55.

Okewale, O., \&Adetimirin, A. (2011). Information use of software packages in Nigerian university libraries. Journal of Information Technology Impact, 11(3), 211-224.

Omeluzor, S. U., Adara, O., Ezinwayi, M., Bamidele, A. I., \&Umahi, F. O. (2012). Implementation of Koha integrated library management software (ILMS): the Babcock University experience. Canadian Social Science, 8(4), 211-221.

Paul, O. (2010). Koha developer wiki. Koha users around the world. Retrieved May 18, 2019.

ProjektlinkKonsult Limited (2010). Introducing Koha, An integrated library management system.Blue Print Concept, Ibadan, Nigeria.

Riewe, L. M. (2008). Survey of open source integrated library systems.

Tella, A., Dina, N., Olaniyi, O. T., Memudu, S. A., \&Oguntayo, S. A. (2017).Assessment of the Use of Koha Library Software in four Selected University Libraries in Nigeria. Journal of Applied Information Science and Technology, 10(2).

Ukachi, N. B., Nwachukwu, V. N., \&Onuoha, U. D. (2014, July). Library automation and use of open-source software to maximise library effectiveness. In Information and Knowledge Management (Vol. 3, No. 4, pp. 74-82).

Zico, M. (2009). Developing an Integrated Library System (ILS) using open source software Koha (Doctoral dissertation, BRAC University). 